BNL 848 (T-334)

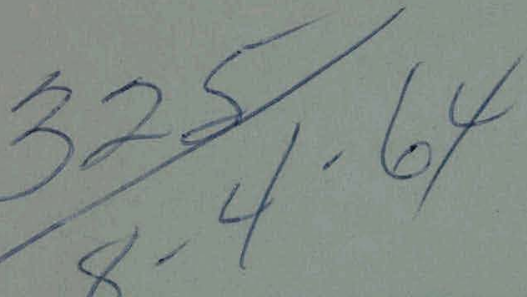

\title{
FABRICATION OF BNL STANDARD COBALT-60 SOURCE
}

A. OLtMANn AND O.A. KUHL

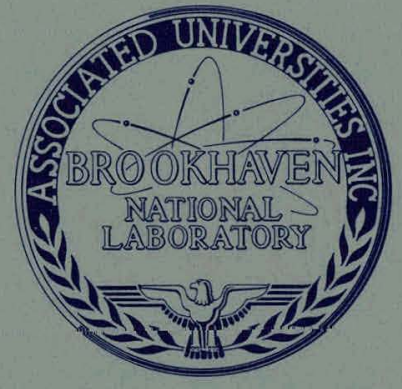

February 1964

BROOKHAVEN NATIONAL LABORATORY ASSOCIATED UNIVERSITIES, INC. under contract with the UNITED STATES ATOMIC ENERGY COMMISSION 


\section{DISCLAIMER}

This report was prepared as an account of work sponsored by an agency of the United States Government. Neither the United States Government nor any agency Thereof, nor any of their employees, makes any warranty, express or implied, or assumes any legal liability or responsibility for the accuracy, completeness, or usefulness of any information, apparatus, product, or process disclosed, or represents that its use would not infringe privately owned rights. Reference herein to any specific commercial product, process, or service by trade name, trademark, manufacturer, or otherwise does not necessarily constitute or imply its endorsement, recommendation, or favoring by the United States Government or any agency thereof. The views and opinions of authors expressed herein do not necessarily state or reflect those of the United States Government or any agency thereof. 


\section{DISCLAIMER}

Portions of this document may be illegible in electronic image products. Images are produced from the best available original document. 
BNL 848 (T-334), February 1964

Fabrication of BNL Standard Cobalt-60 Source

A. Oltmann and O. A. Kuhl

ERRATA and AMENDMENTS

Page 2, Figure 2 - Delete scale

Page 3, Figure 4 - Should read,

Details of stainless steel parts, second encapsulation.

Page 4, Figure 6 - Should read,

Details of first encapsulation.

Page 10, Figure 22 - Delete scale

Page 4, Figure 6 - 12" Dimension should be $12 \frac{1}{2} "$ before weld.

Page 15, par. 3.6 - width should be .735 - .740 in.

Page 23, Fig.

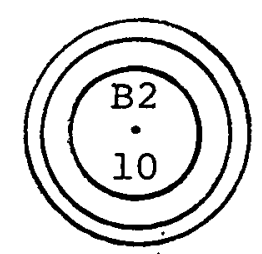

should be

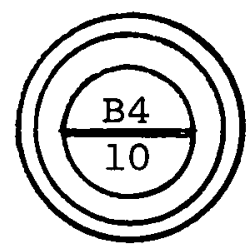

Last paragraph of section 7.9 should read:

$A$ dot will be added on one end only to designate the

"A" end (see BNL inspection sheet). A line 1/32 in. wide and

$1 / 32$ in. deep will be added to the other end starting with the B4 batch. 


\title{
FABRICATION OF BNL STANDARD COBALT-60 SOURCE
}

\author{
A. Oltmann and 0.A. KuHL
}

\section{February 1964}

BROOKHAVEN NATIONAL LABORATORY UPTON, NEW YORK 


\section{LEGAL NOT I G E}

This report was prepared as an account of Government sponsored work. Neither the United Sides, nur the Commission, nor any person acting on behalf of the Ciommission:

A. Makes any warranty or representation, expressed or implied, with respect to the accuracy, completeness, or usefulness of the information contained in this report, or that the usc of any inturmatiun, apparatus, method, or process disclosed in this report. liray nui inlringe privately owned rights; or

B. Assumes any liabilities with respect to the use of, or for damages resulting from the use of any information, apparatus, method, or process disclosed in this report.

As used in the above, "person acting on behalf of the Commission" includes any employee or contractor of the Commission, or employee of such contractor, to the extent that such employee or contractor of the Commission, or employee of such contractor prcparcs, disseminates, or provilles neress to, any information purcuant to his cmployment or contract with the Commission, or his employment with such contractor.

\section{P.RINTED IN USA}

\section{PRICE 75 CENTS}

Available from the Office of Technical Services

Department of Commerce Washington 25, D.C. 


\begin{abstract}
The BNL standard source is a cobalt- 60 gamma irradiation source consisting of a strip of cobalt approximately 12 inches long which has been doubly encapsulated in stainless steel, once before activation and again after activation. In this report a description is given of the procedures and equipment used in the preparation and fabrication of these sources to meet the specifications of the Savannah River Plant (SRP).
\end{abstract}




\section{FABRICATION OF BNL STANDARD COBALT-60 SOURCE}

\section{FIRST ENCAPSULATION}

The design criteria for the first encapsulation of the BNL standard source (Figures 1 and 2) are listed in detail in the appendix, entitled "BNL Spec R155-W1." This specification not only describes the raw materials that must be used, but also details the cleaning and handling procedures that must be observed during fabrication. Physical sizes of the various components and inspection requirements are also given in great detail.

A development program was initiated at BNL, and at its conclusion a method of fabrication was evolved with which parts were produced that were acceptable to E.I. du Pont de Nemours and Co. for activation at SRP.

\section{Fabrication Procedures and Equipment}

Raw Materials. None of the materials used in the fabrication of the source and the outer can were available at the BNL Metals Warehouse. A description of the required material is given below, together with the sources of supply.

The cobalt strips were of $99.5 \%$ pure cobalt, made by a powder metallurgy process, rolled, slit, and ground to size as shown in Figure 3. Two sources of supply were used, namely, the Kulite Tungsten Corp. of Ridgefield, N. J., and SherrittGordon Mines, Ltd., of Canada. The stainless steel tubing was standard warehouse stock, redrawn to BNL tolerances and cut into the exact length required (see Figure 4). J. Bishop and Co. of Malverne, Pa., furnished this part.

The aluminum parts were made by Alcoa. The outer can was drawn from a 1245 alloy, the " $D$ " bars were extruded from 6063 alloy, and the end caps were impact-extruded from 1245 sheet stock and then finish machined. This expensive method of fabrication was used to avoid the possibility of minute lengthwise cracks or "micropipes."

All the above suppliers submitted certified material analyses with their shipments. All parts were inspected by the BNL Quality Control Group. The cobalt received $100 \%$ inspection, as did the small stainless steel end pieces which were made by a local machine shop.
The stainless steel tubes and the aluminum end pieces received about $15 \%$ inspection. The aluminum tubing and extrusion, which came in 20 -foot lengths, received a thorough sample inspection for drawing tolerances and $100 \%$ inspection for general finish and straightness.

Fabrication. The detail parts are machined to the dimensions shown in Figures 2 to 6, inspected for compliance with the drawing tolerances, and then cleaned as specified in the appendix.

The stainless steel tubes are flattened in three steps, as shown in Figures 7 to 10, with use of a hardened tool steel die and an internal strip to prevent bowing. No lubricants are used in these steps, and white cotton gloves are worn. These parts are again inspected and given, a methanol bath with subsequent hot air drying. One end piece is then welded in place (see Figure 11). The press used for flattening the tubes, all cleaning equipment, and the final assembly bench are located in a "clean room" (Figure 12).

The cobalt strip is then inserted into the partially completed sheath, and the last end piece is put in place. Again white gloves are worn to prevent contamination of the parts. Both the cobalt and the stainless steel end pieces are given a methanol bath and a hot air drying before insertion. The final weld is then made, and the finished assemblies are leak-tested (Figures 13 to 15 ). The assemblies that pass the leak test are cleaned again and stored in plastic bags. Those that do not pass are taken apart, the cobalt strip is cleaned for reuse, and the rest of the assembly is thrown away. Experience with "leakers" has been very good; rejects average about $1 \%$. The next operation is to clean all the aluminum parts as described in the appendix. The end caps are then numbered in accordance with the numbering system described in section 7 of the appendix. One end cap is welded to the externally chamfered end of the aluminum tube.

The aluminum " $D$ " hars have been separated into 3 or 4 piles according to thickness. The encapsulated cobalt strips are given a final flattening to remove all springback, thicknesses are measured, all strips are weighed, and an average weight 


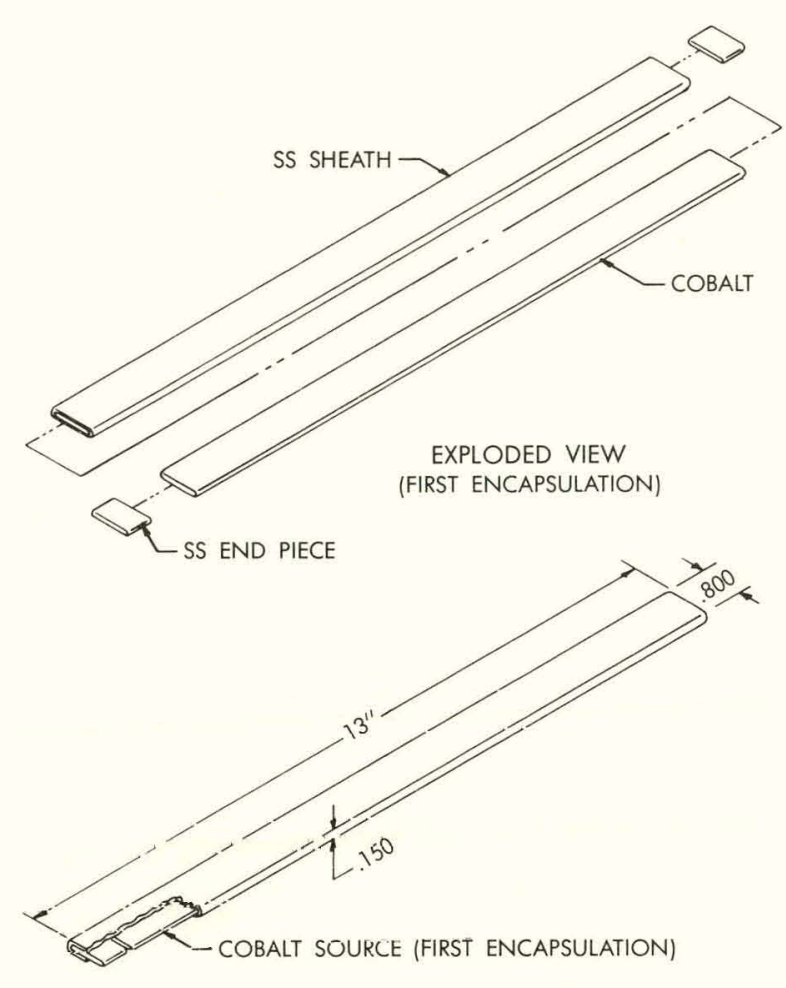

Figure 1. BNL standard source.

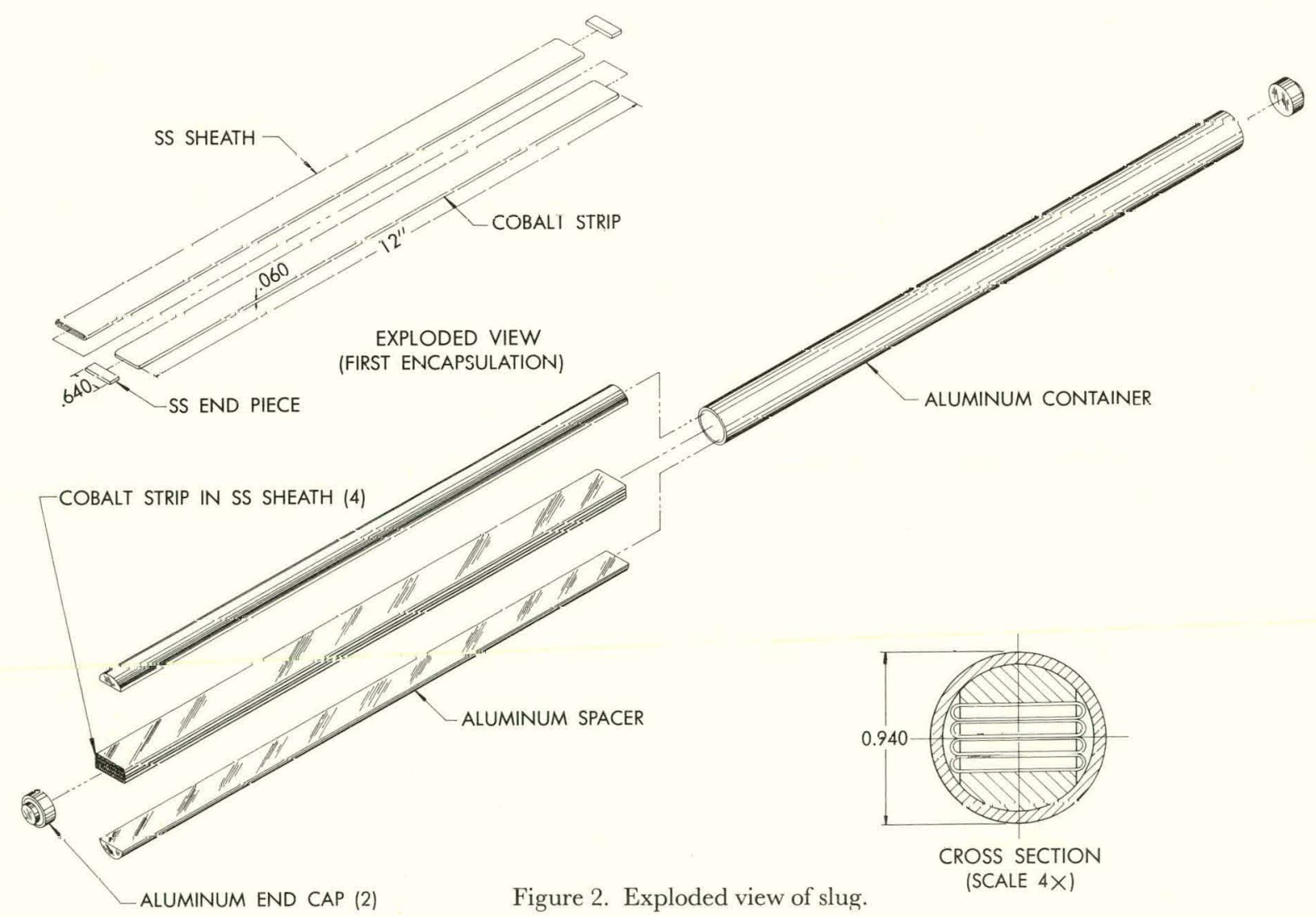



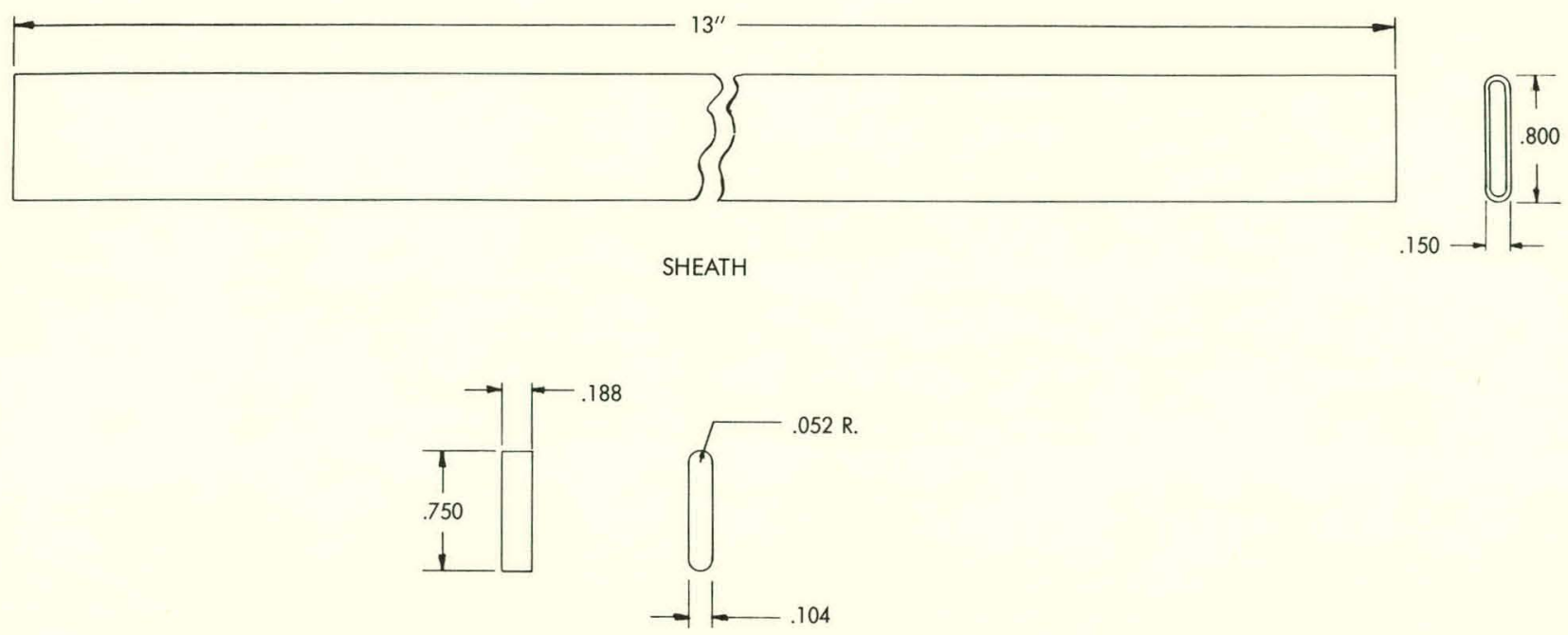

END PIECE

Figure 4. Details of stainless steel parts, first encapsulation.
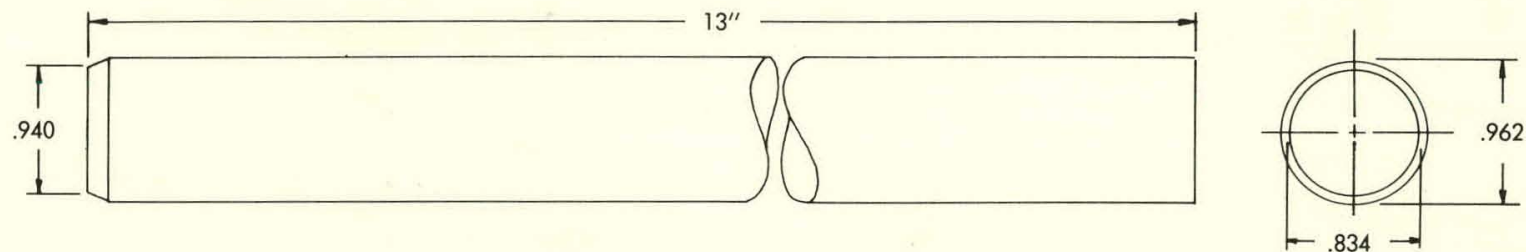

OUTER TUBE
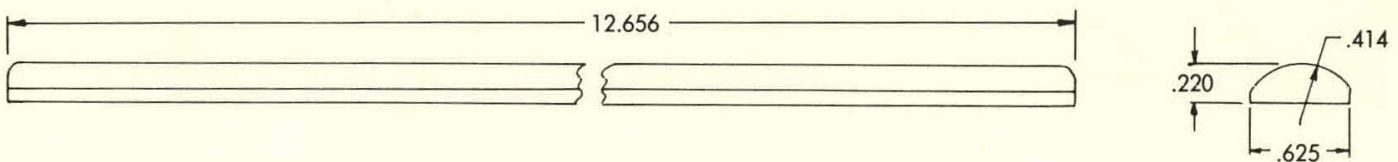

FILLER BAR
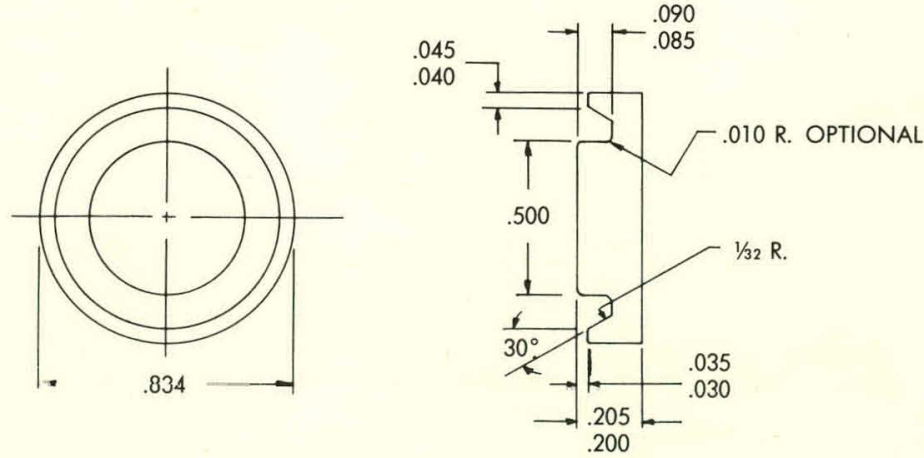

END PLUG

(SCALE $2 \times$ )

Figure 5. Details of aluminum parts, first encapsulation. 

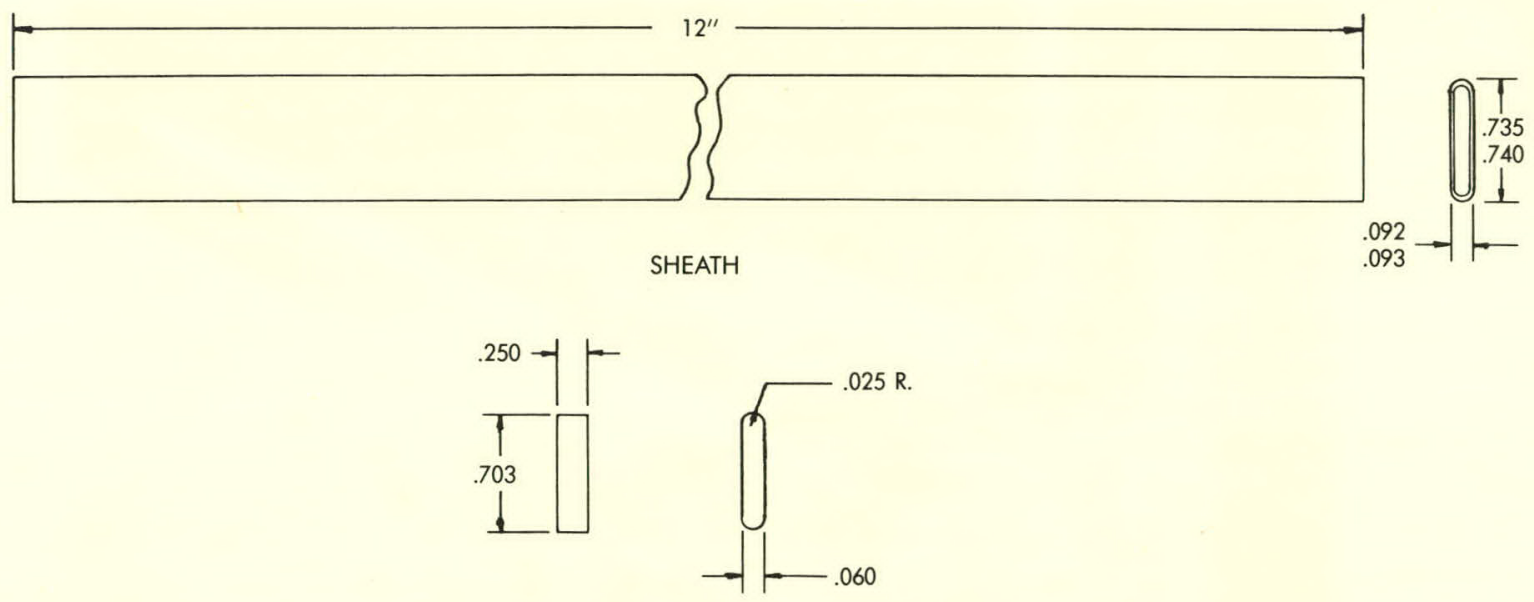

END PIECE

Figure 6. Details of second encapsulation.

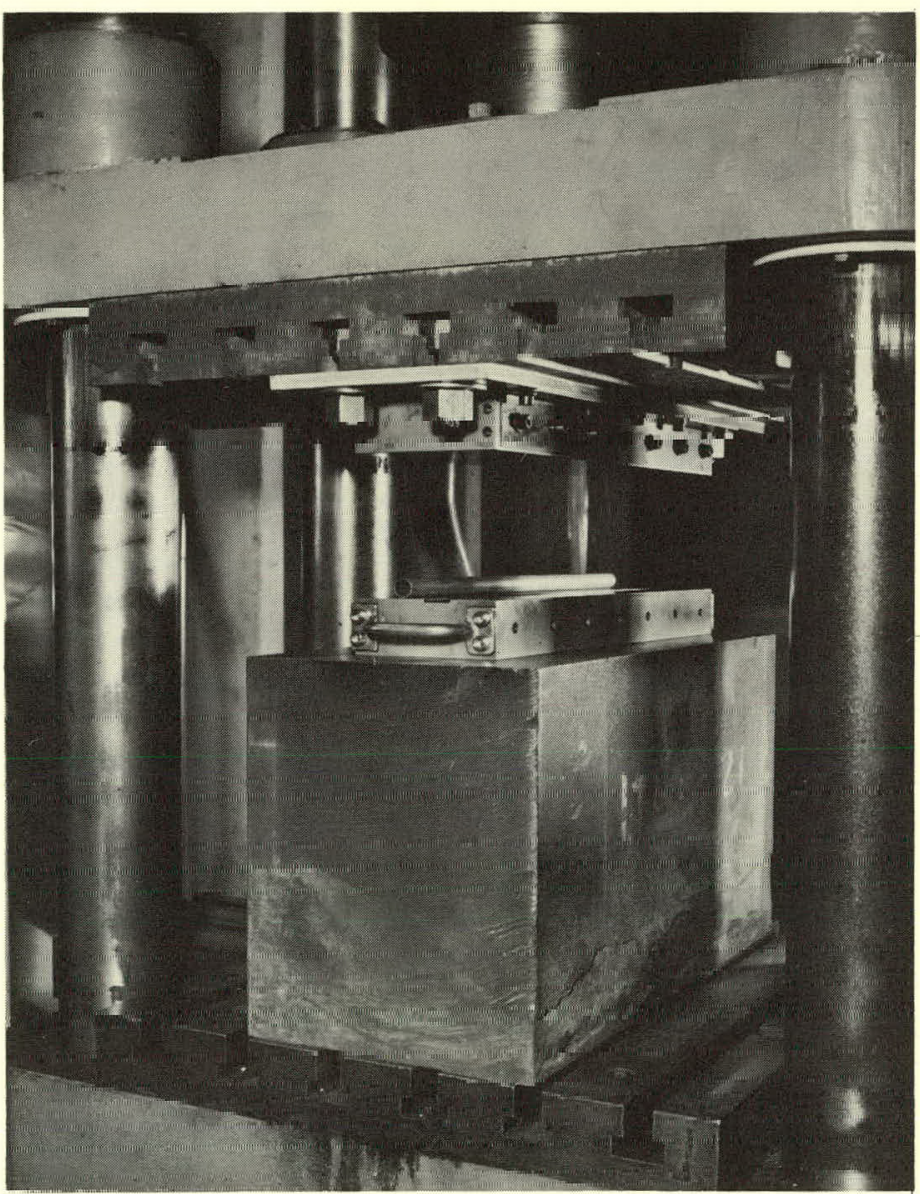

Figure 7. Sheath before flattening.

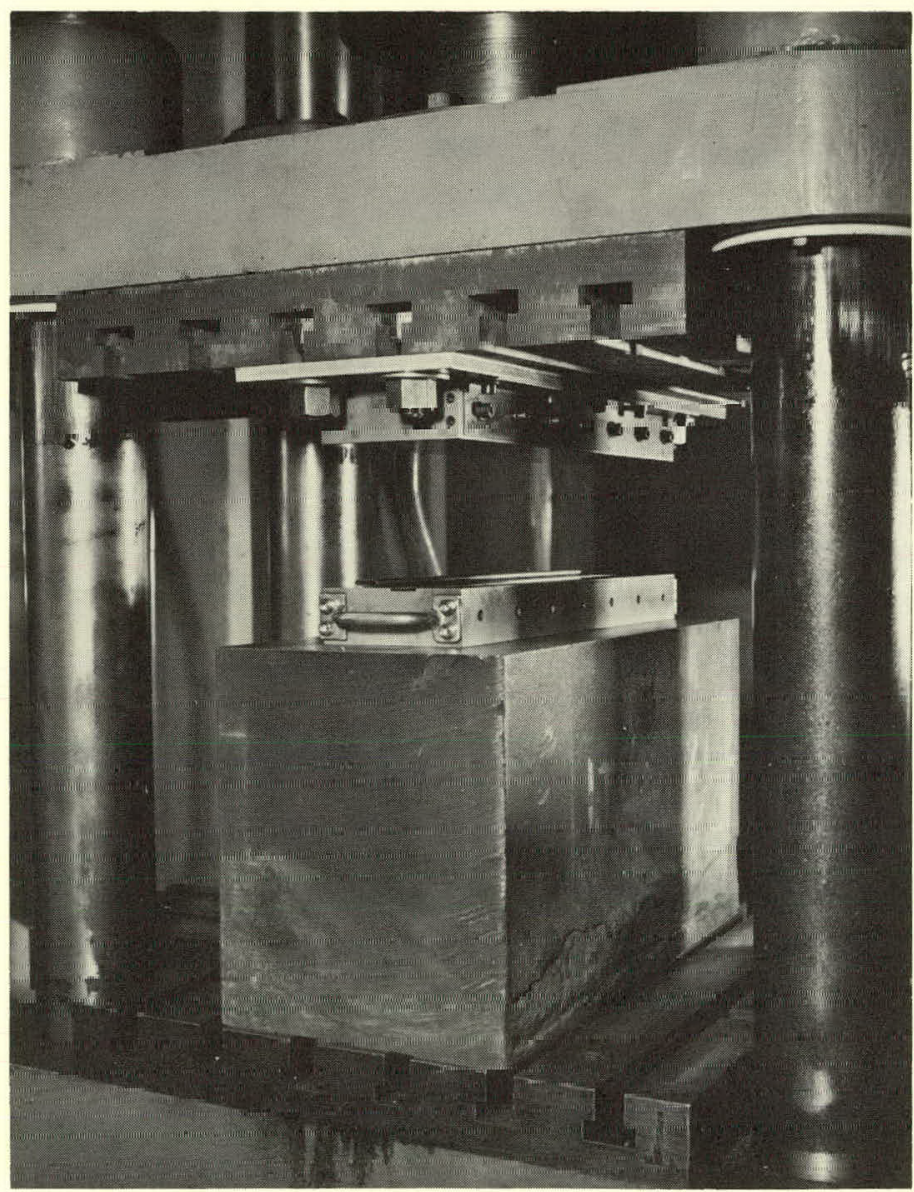

Figure 8. Sheath flattening, first stage. 


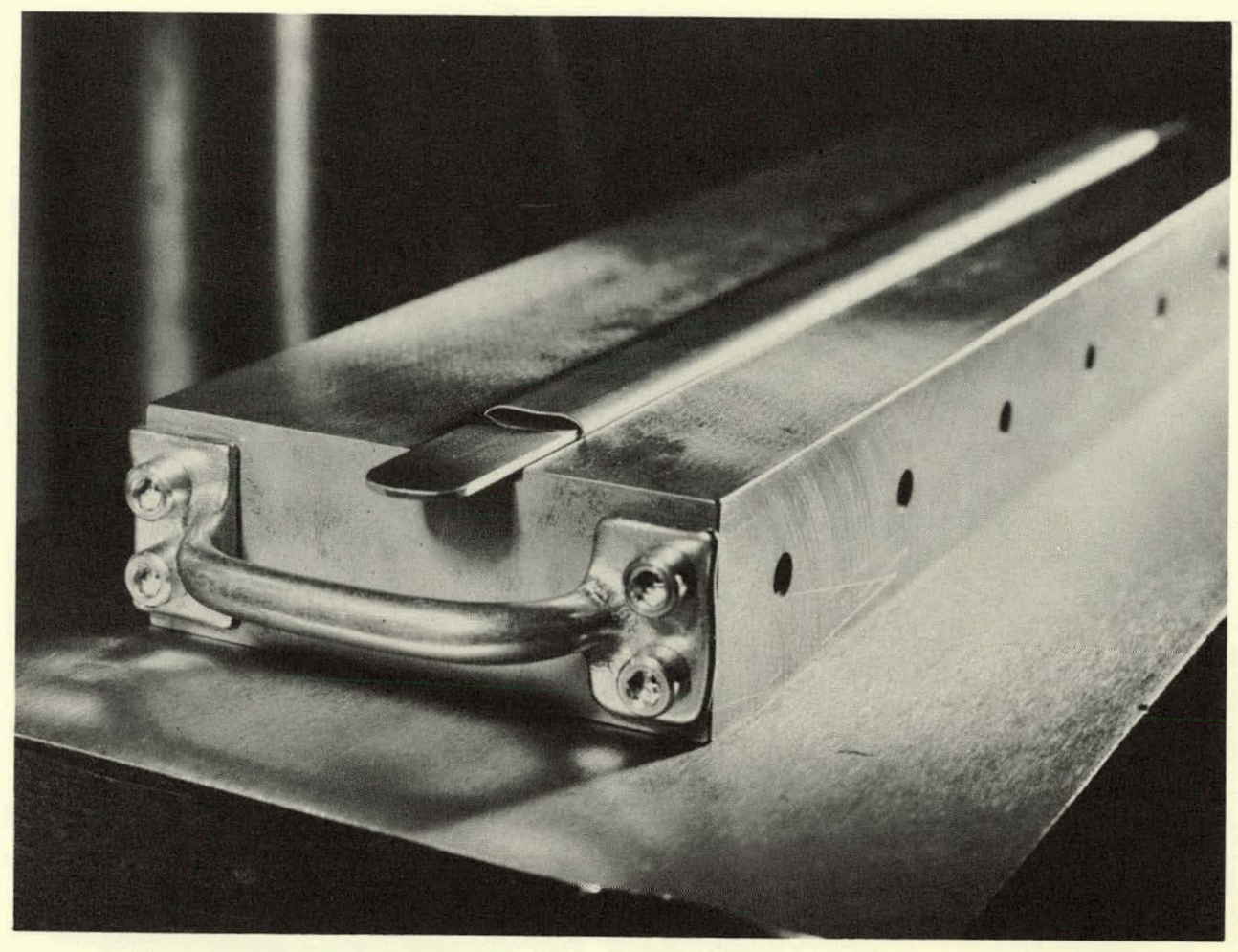

Figure 9. Sheath flattening, second stage.

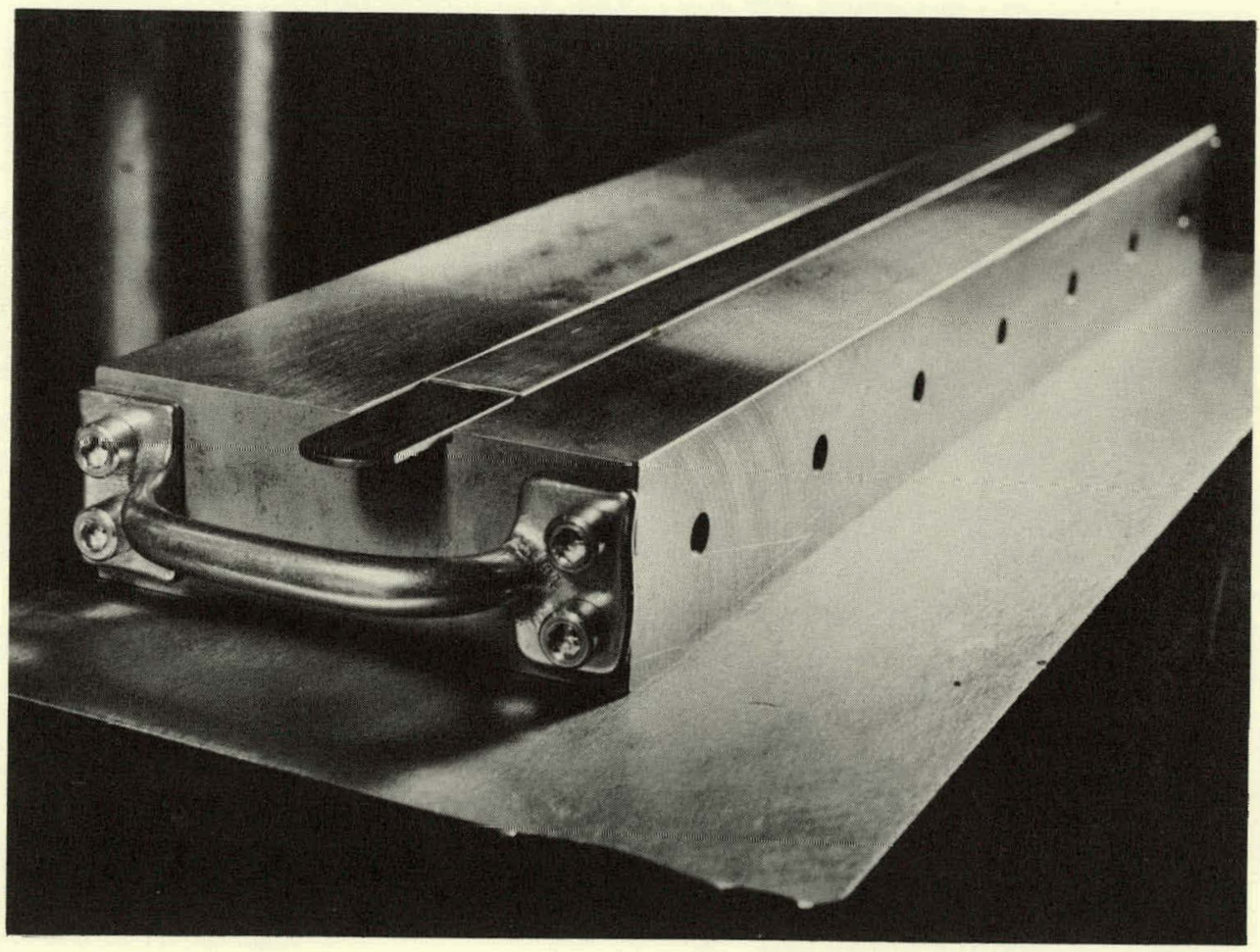

Figure 10. Sheath flattening, final stage. 


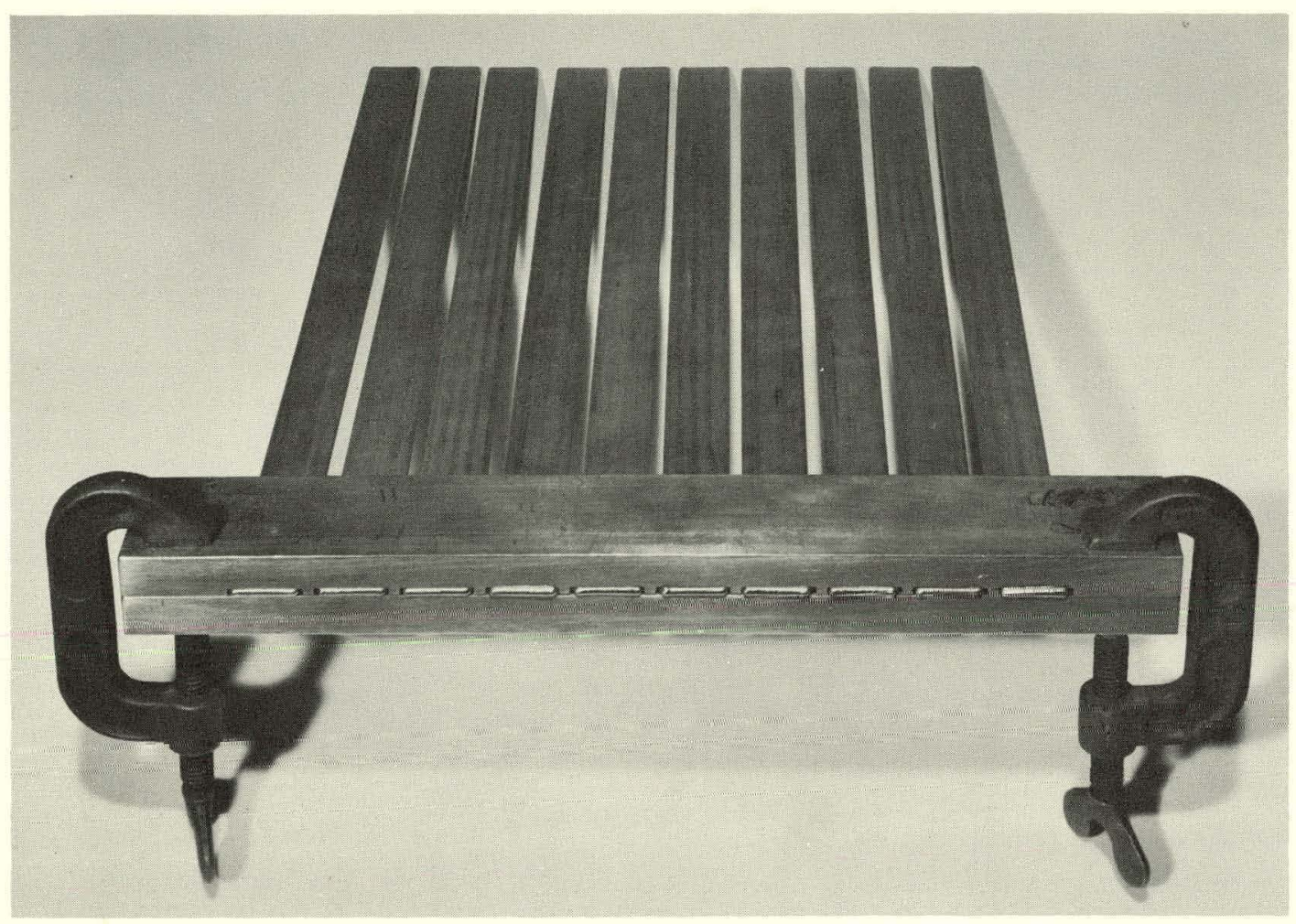

Figure 11. Stainless steel welding jig.

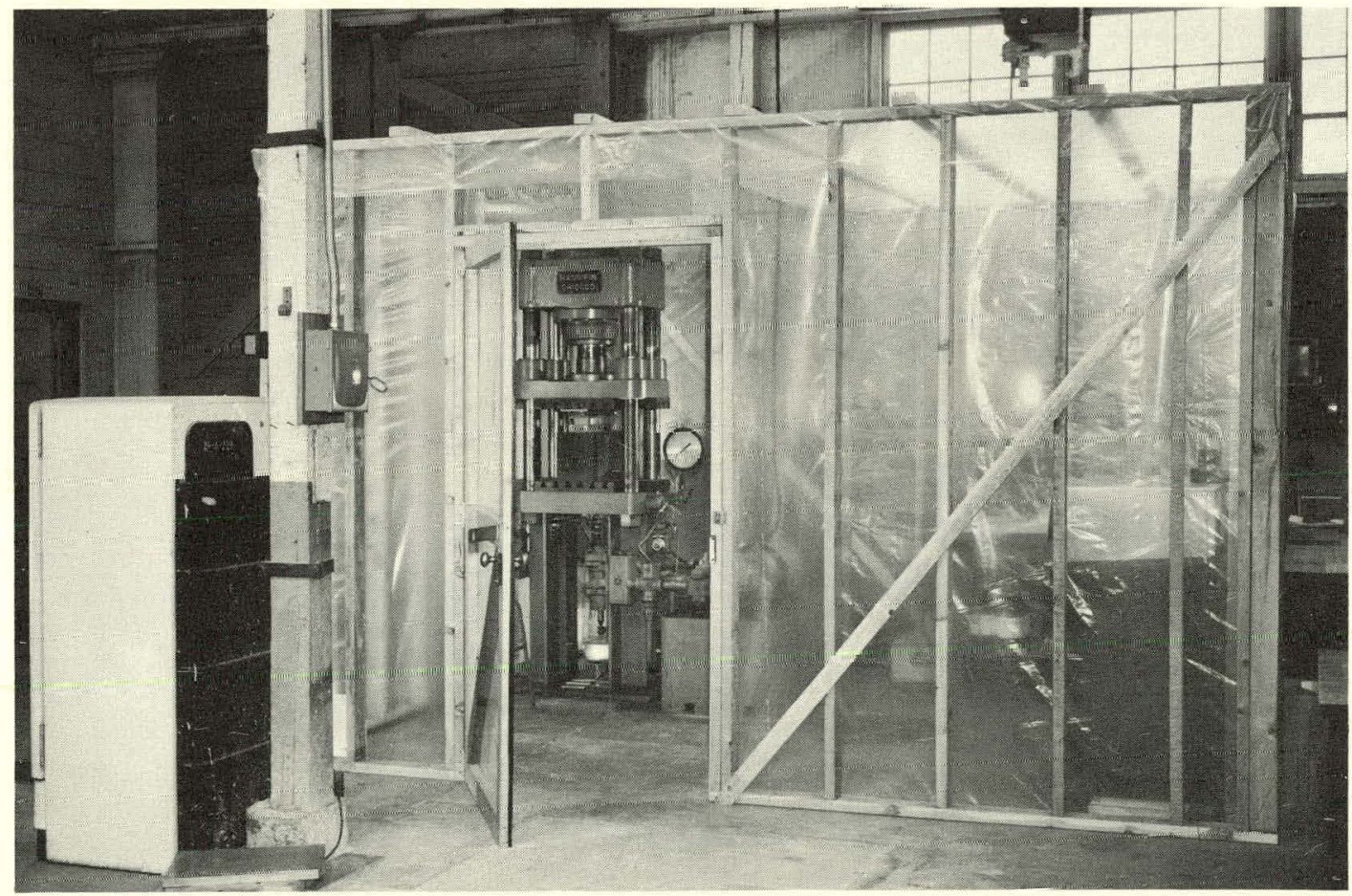

Figure 12. "Clean room." 


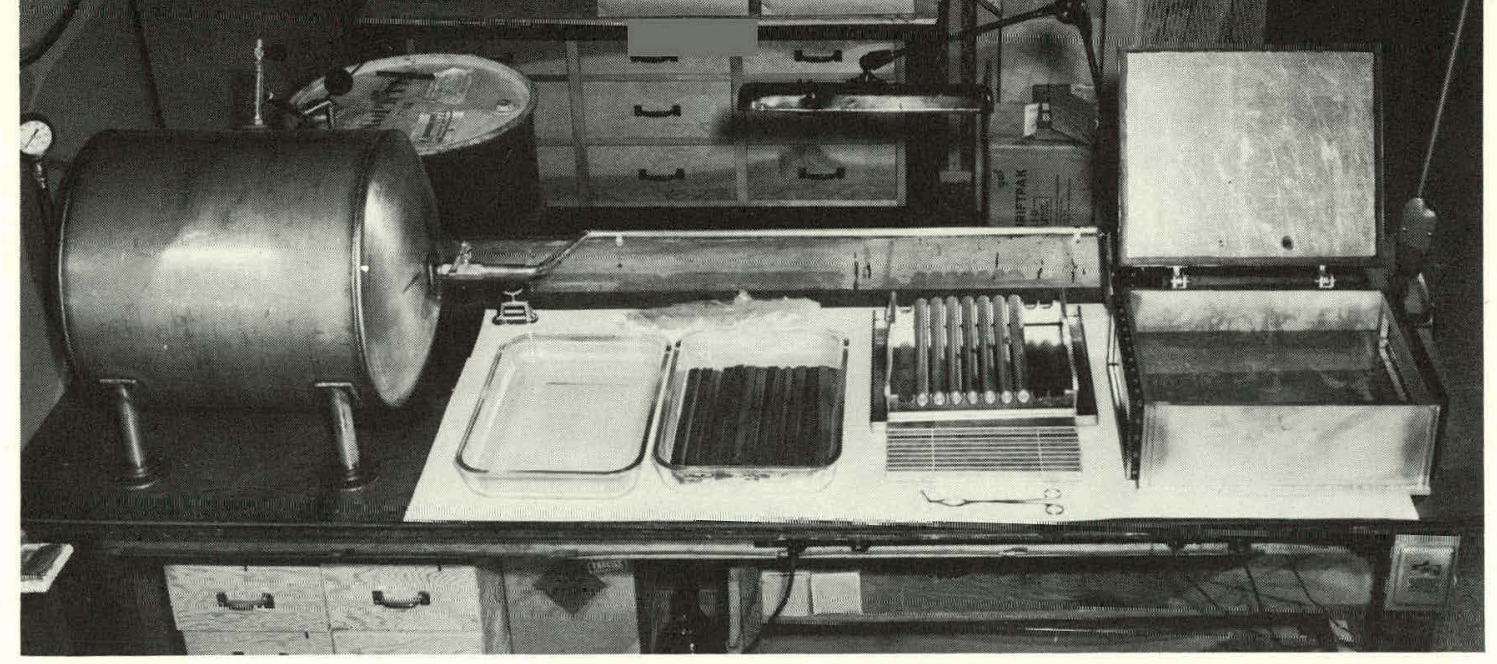

Figure 13. Leak-testing equipment.

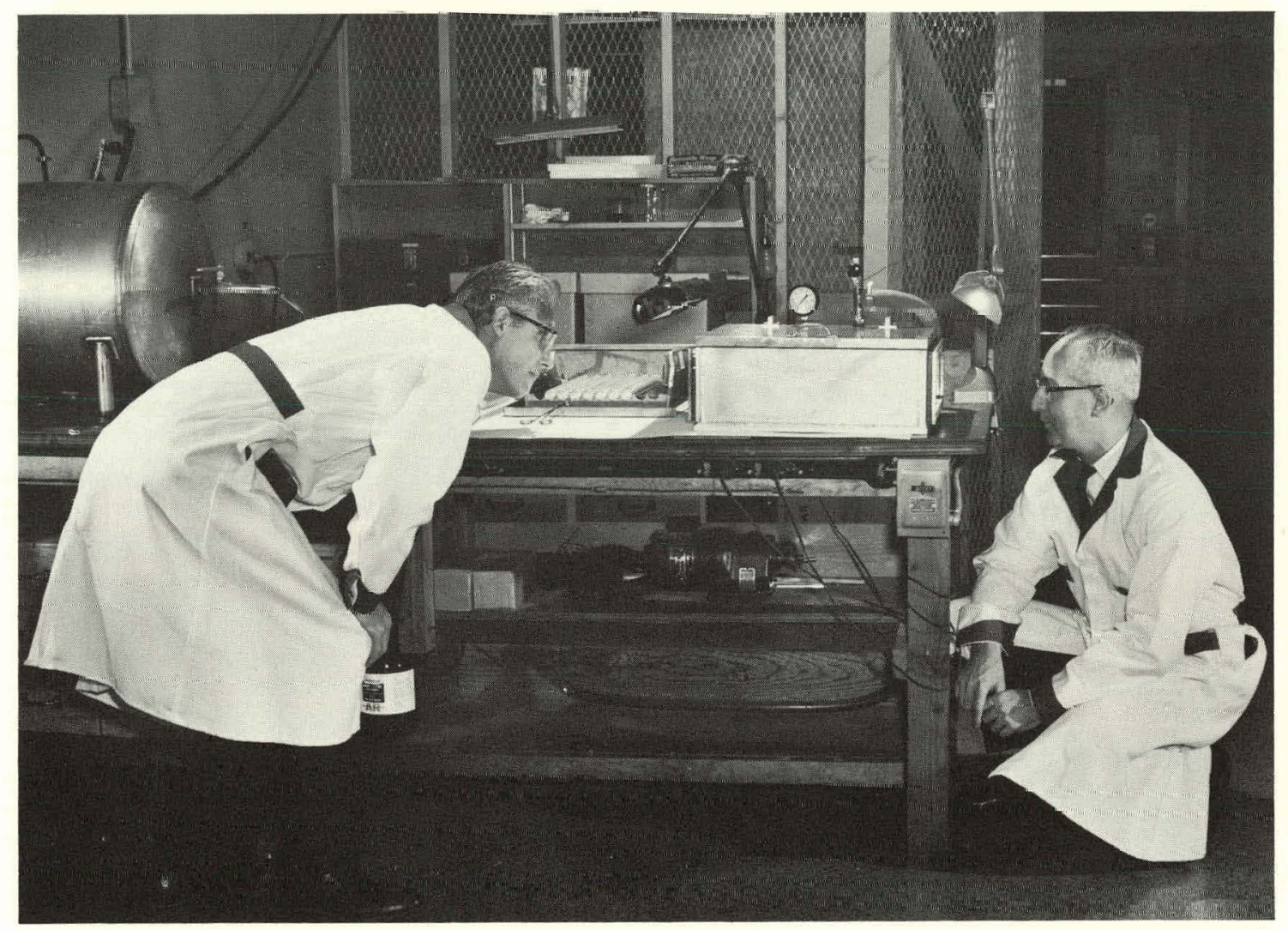

Figure 14. Leak-testing of encapsulated cobalt strips.

Figure 15. Close-up of test specimen.

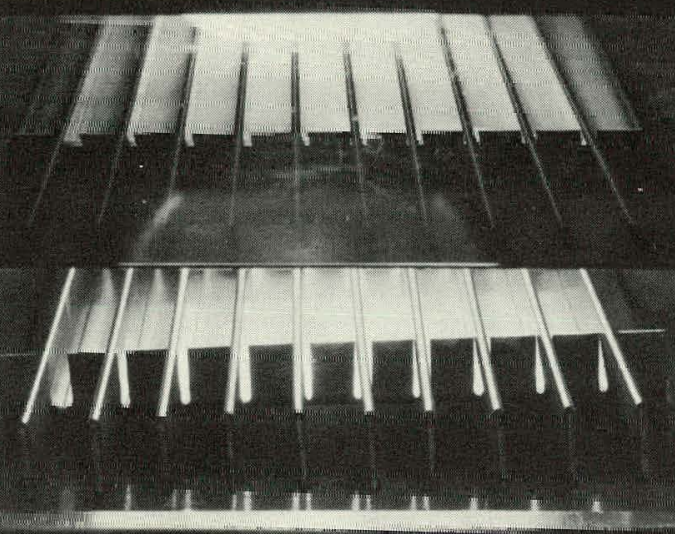




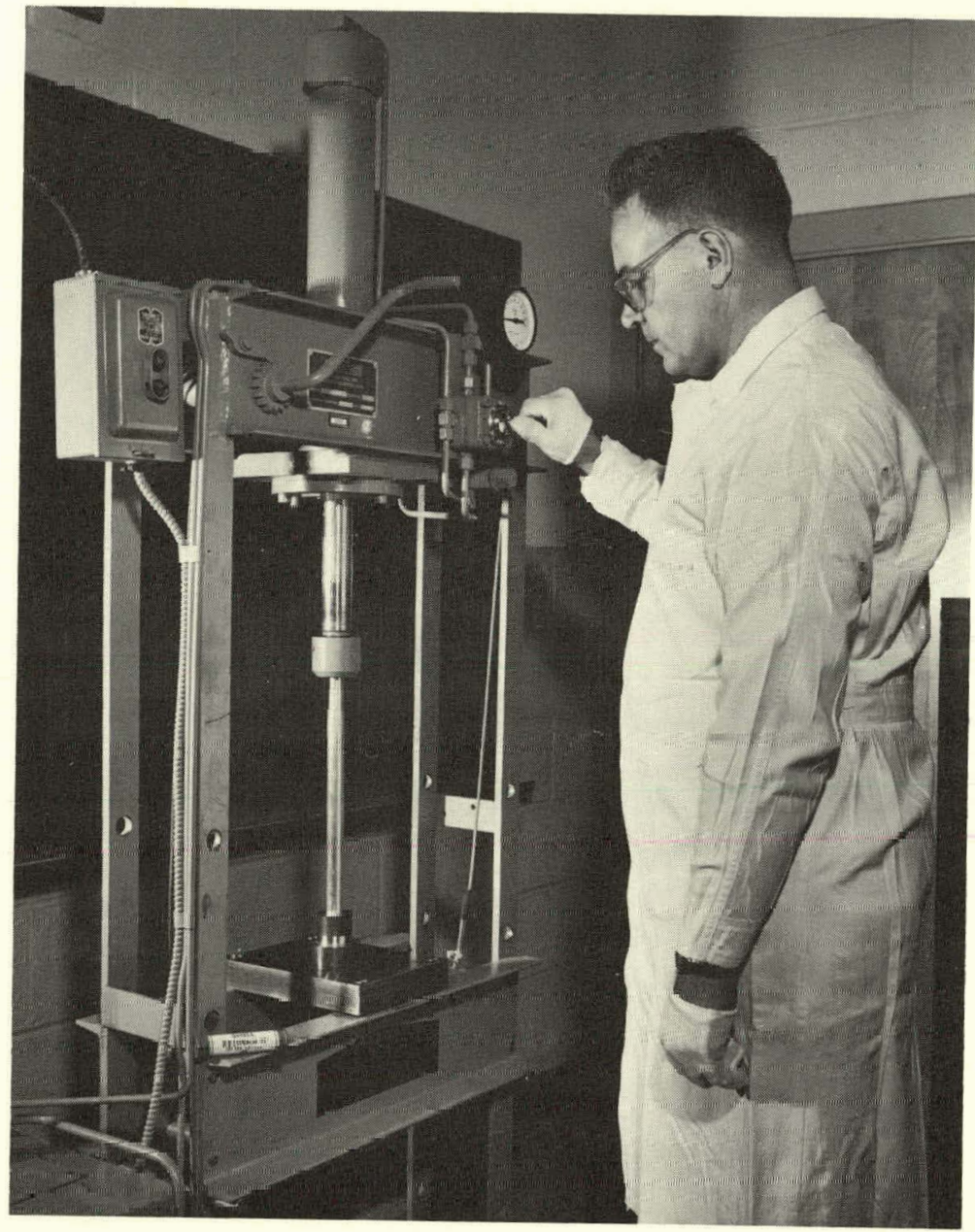

Figure 16. Die-sizing equipment.

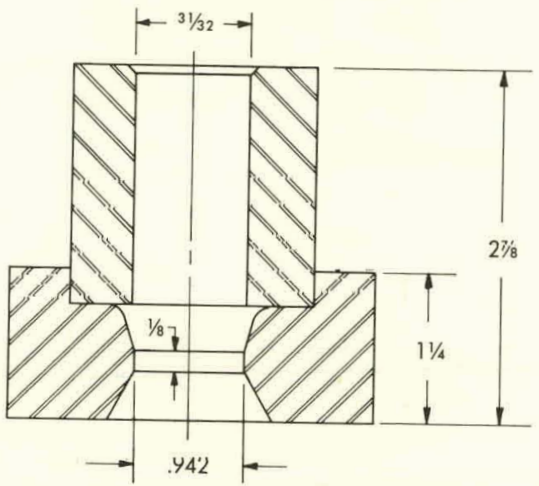

Figure 17 netail of sizing dic.

Figure 18. BNL tube gange.

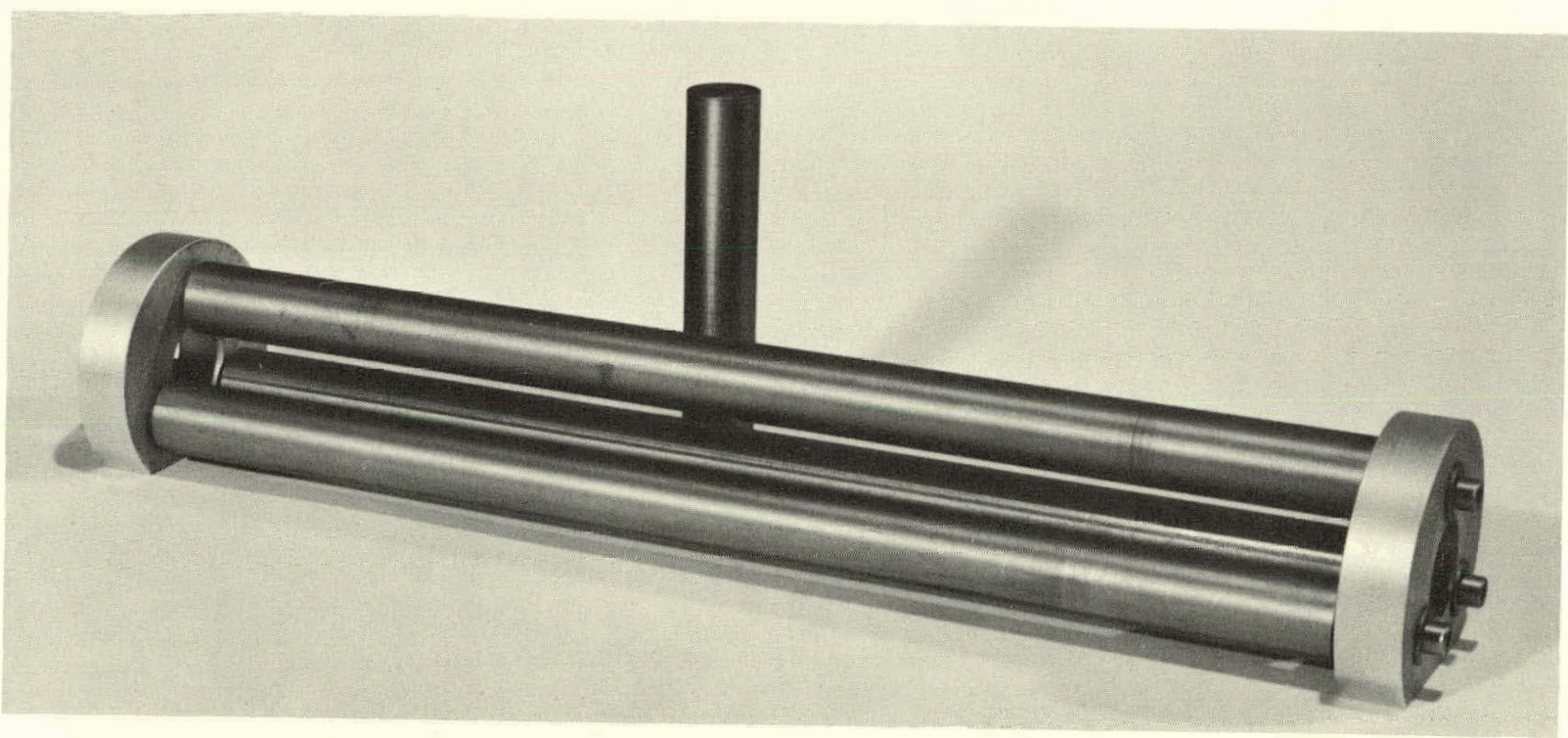


is established. Four strips at a time are then selected to produce a uniform weight for each slug. Total thicknesses are established and proper pairs of " $D$ " bars are selected to produce a sandwich measuring from 0.835 to 0.838 in. in o.d. The i.d. of the tube is $0.834 \mathrm{in}$. An apparent interference fit is obtained. The assembly is made by using an arbor press. The open end is closed with a rubber stopper until ready for the next step, the die-sizing operation shown in Figure 16. This is the critical step, and any errors in workmanship or judgment in selecting the pieces of the sandwich will be apparent at this time. The die-sizing step consists of pushing a 0.962 -in.-o.d. tube through a die (Figure 17) with a 0.942 -in. hole. The metal is actually displaced all along the length of the tube, which makes the tube about $5 / 8$ in. longer. Shell DoorEase is used as a lubricant for this operation. The tight-fitting internal arbor prevents the lubricant from entering the slug. This lubricant is carefully removed, the arbor pulled out, and a rubber stopper inserted. The slug is then checked for straightness and outside dimensions by using the tube gauge shown in Figure 18.

The excess material is removed after the tightfitting end cap has been put on. The cap is dipped into methanol, and the slug is put into a drying oven at $\approx 275^{\circ} \mathrm{F}$ to remove any moisture within it. The end cap is then welded in place, and the whole assembly is leak-tested.

At times a small pinhole can be seen with a magnifying glass. This is caused by blowback from the hot gases formed in the tube and can be eliminated without difficulty before leak-testing. All gross leakers are cut apart and the four encapsulated cobalt strips are salvaged.

The finished slugs are leak-tested in the equipment shown in Figure 13. After this the slugs are

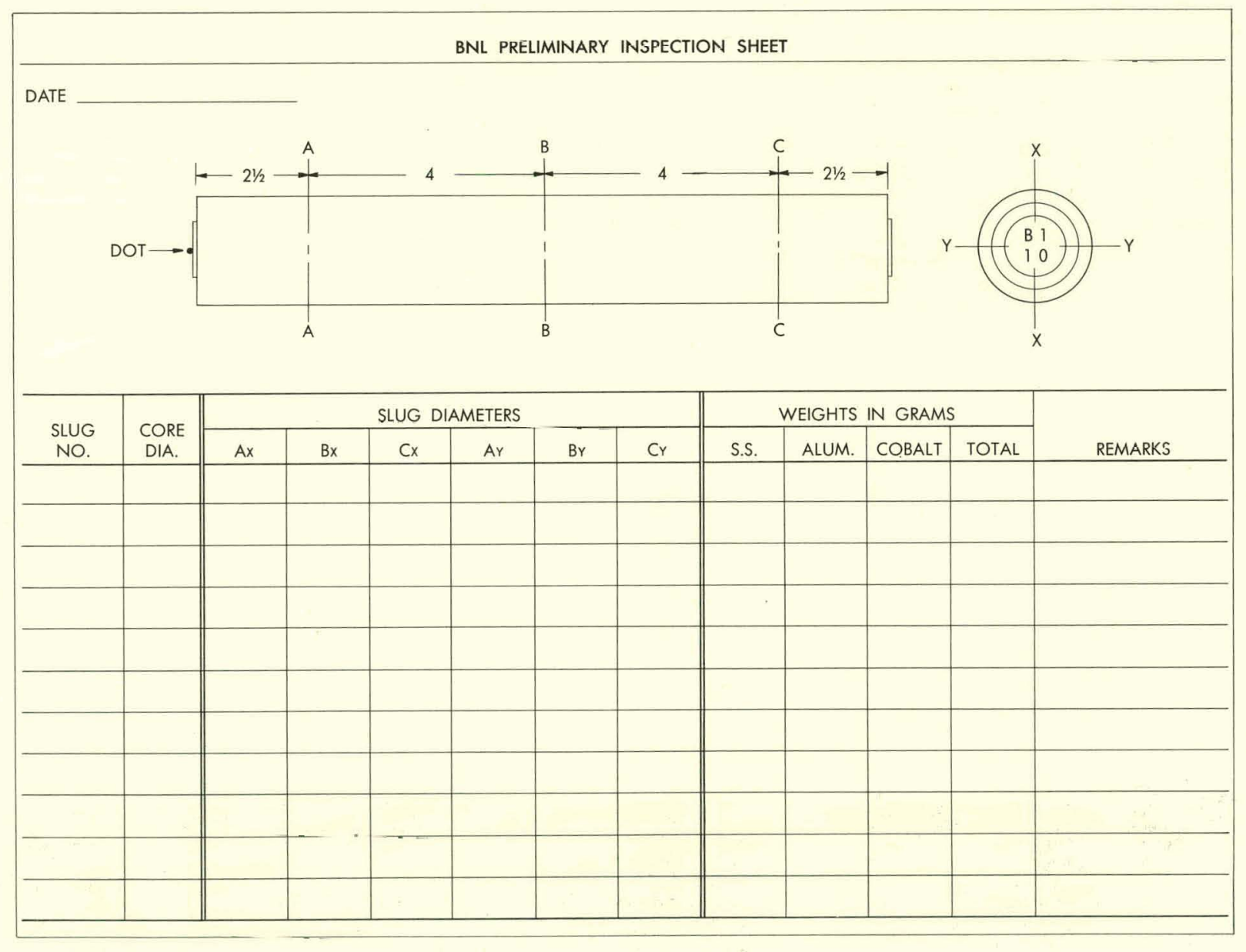

Figure 19. 
TO:

DATE:

FROM

BNL COBALT SLUG, METALLURGICAL EXAMINATION

SLUG NO.
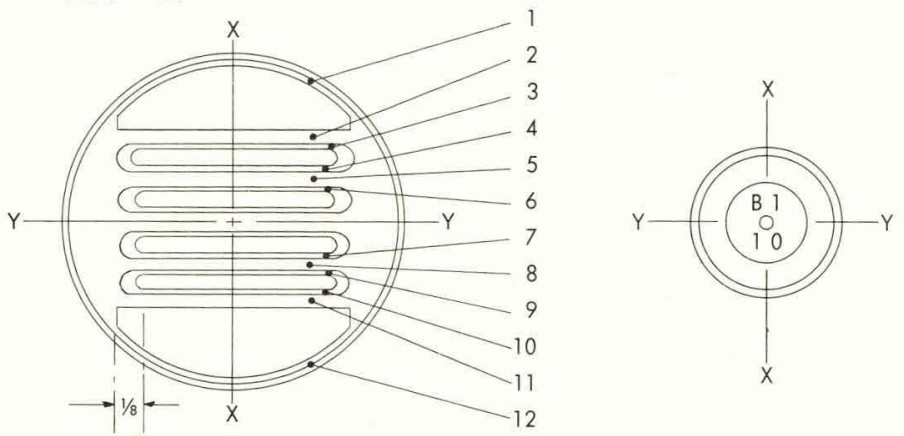

MEASUREMENT POSITION:

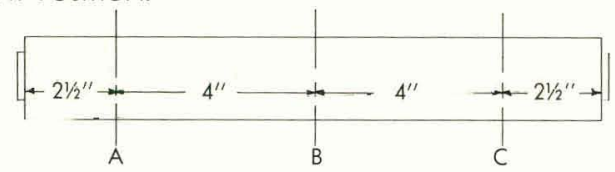

GAP MEASUREMENT, MILS

\begin{tabular}{|c|c|c|c|c|c|c|c|}
\hline \multirow{4}{*}{$\begin{array}{l}\text { LOCATION: } \\
1 \mathrm{Al}-\mathrm{Al}\end{array}$} & \multicolumn{6}{|c|}{ POSITION } & \multirow{3}{*}{ AVERAGE } \\
\hline & \multicolumn{2}{|c|}{$\mathrm{A}$} & \multicolumn{2}{|c|}{ B } & \multicolumn{2}{|c|}{ C } & \\
\hline & EDGE & CENTER & EDGE & CENTER & EDGE & CENTER & \\
\hline & & & & & & & \\
\hline $2 \mathrm{Al}-\mathrm{S}$ & & & & & & & \\
\hline $3 \mathrm{~S}-\mathrm{Co}$ & & & & & & & \\
\hline $4 \mathrm{Co}-\mathrm{S}$ & & & & & & & \\
\hline $5 \mathrm{~S}-\mathrm{S}$ & & & & & & & \\
\hline $6 \mathrm{~S}-\mathrm{Co}_{0}$ & & & & & & & \\
\hline TOTALS* & & & & & & & \\
\hline 7 Co-S & & & & & & & \\
\hline 8 S-S & & & & & & & \\
\hline 9 S-Co & & & & & & & \\
\hline $10 \mathrm{Co}-\mathrm{S}$ & & & & & & & \\
\hline $11 \mathrm{~S}-\mathrm{Al}$ & & & & & & & \\
\hline $12 \mathrm{Al}-\mathrm{Al}$ & & & & & & & \\
\hline TOTALS* & & & & & & & \\
\hline
\end{tabular}

*SPECIFICATION: 3 MILS (2 MILS MAXIMUM, INDIVIDUAL).

\begin{tabular}{|c|c|c|c|c|c|}
\hline \multirow{6}{*}{$\begin{array}{l}\text { MEASUREMENT } \\
\text { THROAT, MIN. } \\
\text { PENETRATION, MIN. } \\
\text { CLADDIR } 4 G, \text { IVIIIV. } \\
\text { CLADDING, MAX. }\end{array}$} & \multicolumn{2}{|c|}{ ALUMINUM: } & \multicolumn{2}{|c|}{ CLADDING } & \multirow[b]{2}{*}{ C CAP } \\
\hline & A CAP & A & $B$ & C & \\
\hline & & $x$ & $x$ & $x$ & \\
\hline & & $x$ & $x$ & $x$ & \\
\hline & & & & & \\
\hline & & & & & \\
\hline
\end{tabular}

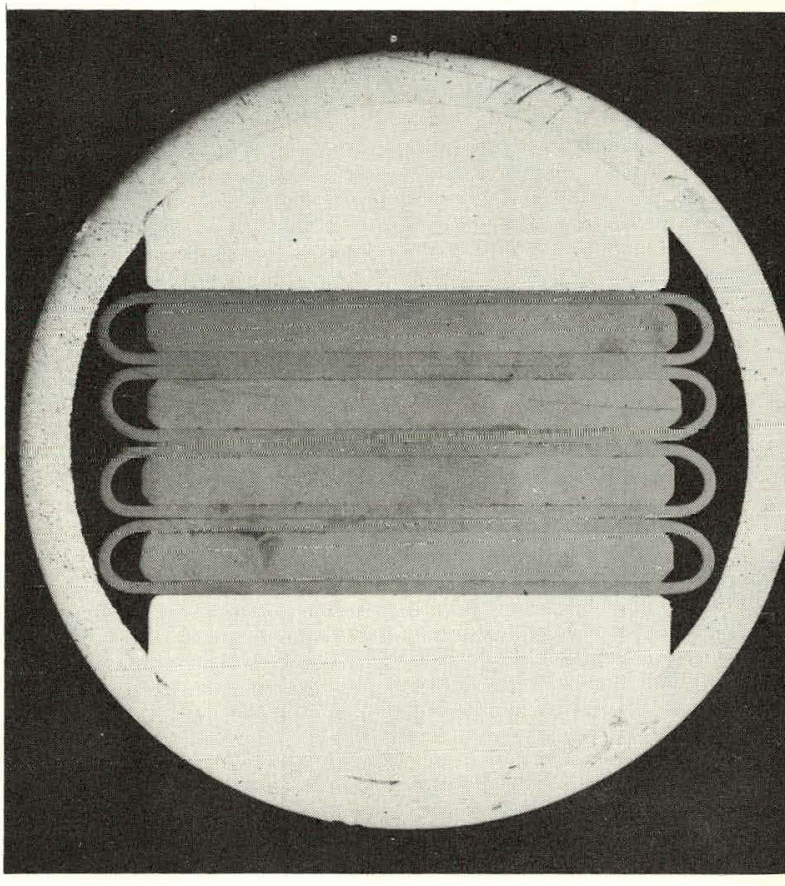

Figure 22. Typical cross section of slug. $(6 \times$. 
weighed and the diameters are measured in two planes at the three places where SRP will cut and prepare the test sections. This information is recorded for all slugs on the form shown in Figure 19. The slugs are then cleaned with steel wool and hot water, and, after they have dried, are wrapped in a paper towel and inserted into a cardboard tube to protect them during shipping.

Upon arrival at SRP all the slugs are again leaktested and checked for outside dimensions and other items described in the appendix. A number of the slugs are then sectioned (Figures 21 and 22); the sections are polished and examined under a microscope, and the end welds are checked in a comparator. The information is entered on the appropriate form (Figure 20). Evaluation of the slugs is based on the requirements given in section 7 of the appendix.
Equipment and Tooling. Besides the run-of-the mill machine shop equipment, such as lathes, milling machines, an arbor press, and a buffing wheel, the only major pieces of equipment used are the following:

1. Hannifin 75-ton hydraulic press (Figure 12).

2. Tempco 25-ton hydraulic press with 18-in. stroke (Figure 16).

3. Tube gauge made by BNL (Figure 18).

4. Leak-test apparatus made by BNL (Figures 13 and 14).

\section{SECOND ENCAPSULATION}

Upon completion of reactor irradiation at SRP, the slug (Figure 2) will be shipped to BNL in a 7ton shipping cask (Figure 23). The aluminum can will be stripped from the four stainless steel encap-

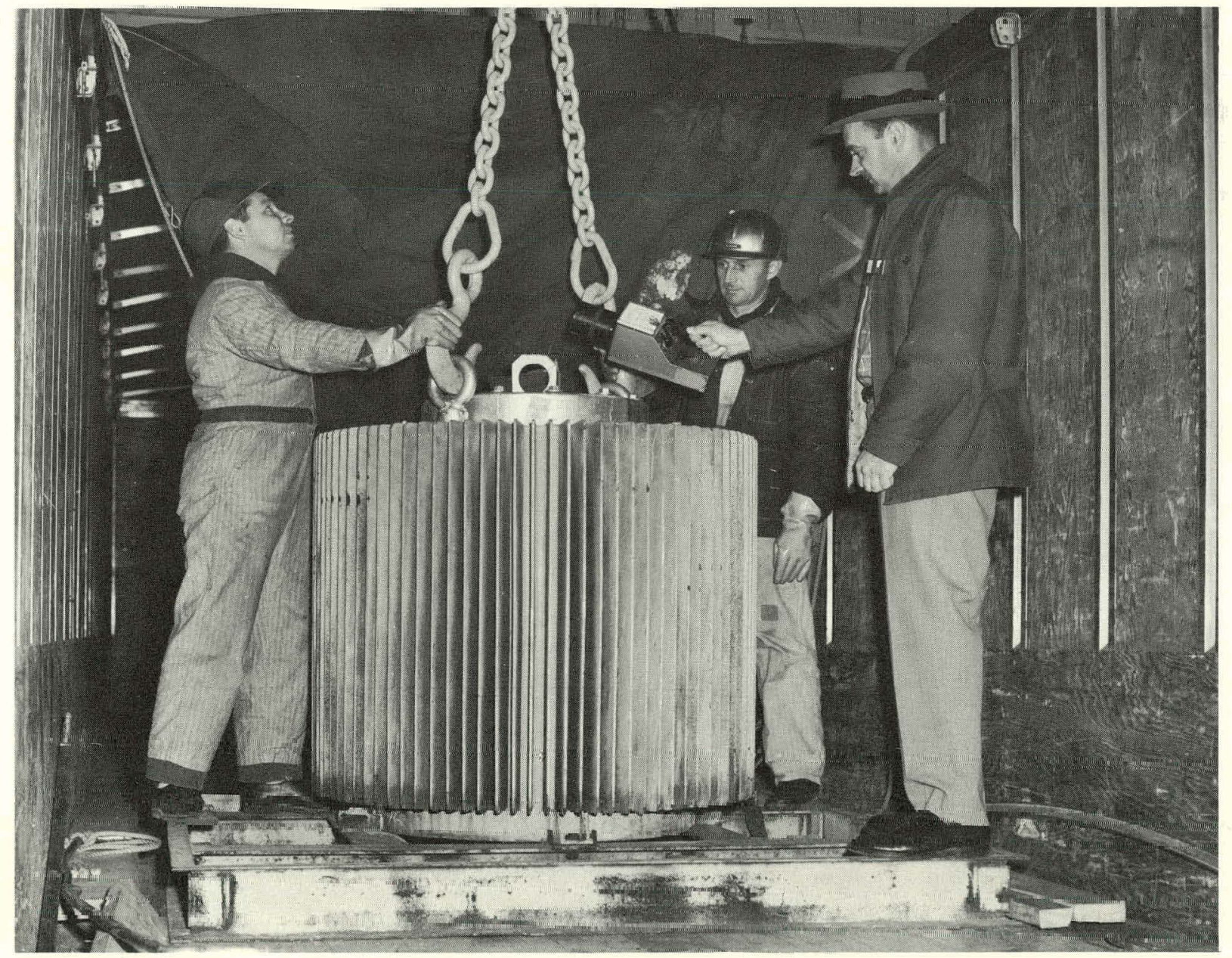

Figure 23. Shipping cask. 


\author{
APPENDIX \\ , \\ BROOKHAVEN NATIONAL LABORATORY \\ Nuclear Engineering Department \\ Engineering Division
}

Spec R155-W1

High Intensity Radiation

Development Laboratory

June 28, 1962

Amended Aug. 29, 1.962

Amended Oct. 17, 1963

\section{PROCEDURE FOR COBALT ENCAPSULATION}

\section{DESCRIPTION}

The cobalt encapsulation is a double encapsulation. It consists of 4 cobalt strips, 0.060 inch thick by 0.640 inch wide by 12 inches long, which are inserted into seamless stainless steel sheaths, flattened to form a tight fit. The sheaths are welded on both ends to form the first encapsulation.

A stack of 4 cobalt strips is inserted between 2 D-bars of 6063 aluminum alloy. The above assembly is pressed into a tube of 1245 aluminum, one end is welded, the whole assembly is diesized, the open end trimmed and another end cap of 1245 aluminum sheet is welded in place. Leak tests are performed both on the stainless steel encapsulation and the final encapsulation. Welding of both stages will be done by a qualified welder using the inert gas tungsten arc method. No filler rod is used in the welding operations.

All materials will be cleaned and inspected thoroughly after each series of operations to maintain high quality throughout.

\section{COMPONENT ALLOYS}

2.1 Cobalt: Reactor grade, minimum purity $99.5 \%$, strips rolled and ground to size.

2.2 Stainless steel: Type 321 for sheath, Type 304 for filler piece.

\subsection{Aluminum: 6063-T6 for D-bars:}

2.4 Aluminum: 1245 or $\mathrm{C}-64$ for can (extrusion).

2.5 Aluminum: 1245 or C -64 sheet for end caps. 


\section{COBALT CHEMICAL COMPOSITION}

$\begin{array}{lc}* \mathrm{Co} & 99.97 \% \\ \mathrm{Ni} & .37 \% \\ \mathrm{Cu} & .005 \% \\ \mathrm{~S} & .001 \% \\ \mathrm{Fe} & .0018 \% \\ \mathrm{C} & .012 \%\end{array}$

*Includes $\mathrm{Ni}$.

\section{ALUMINUM CHEMICAL COMPOSITION}

$\begin{array}{ll}\text { Aluminum } & 99.45-99.60 \% \text { minimum } \\ \text { Copper } & 0.01 \% \text { maximum } \\ \text { Iron plus Silicon } & 0.55 \% \text { maximum } \\ \text { Iron } & 2 \times \mathrm{Si} \text { minimum } \\ \text { Boron } & 0.001 \% \text { maximum } \\ \text { Cadmium } & 0.003 \% \text { maximum } \\ \text { Manganese } & 0.03 \% \text { maximum } \\ \text { Zinc } & 0.03 \% \text { maximum } \\ \text { Titanium } & 0.03 \% \text { maximum } \\ \text { Lithium } & 0.008 \% \text { maximum } \\ \text { Tin } & 0.01 \% \text { maximum } \\ \text { Lead } & 0.01 \% \text { maximum } \\ \text { Bismuth } & 0.01 \% \text { maximum } \\ \text { Chromium } & 0.03 \% \text { maximum } \\ \text { Nickel } & 0.01 \% \text { maximum } \\ \text { Magnesium } & 0.01 \% \text { maximum }\end{array}$

\section{TYPE 321 STAINLESS STEEL COMPOSITION}

$\begin{array}{ll}\text { Carbon } & 0.08 \% \text { maximum } \\ \text { Manganese } & 2.00 \% \text { maximum } \\ \text { Bhosphernus } & 0.04 \% \text { maximum } \\ \text { Sulfur } & 0.03 \% \text { maximum } \\ \text { Silicon } & 1.00 \% \text { maximum } \\ \text { Chromium } & 17.00 \text { to } 19.00 \% \\ \text { Nickel } & 8.00 \text { to } 11.00 \% \\ \text { Titanium } & 0.40 \% \text { minimum } \\ \text { Copper } & 0.15 \% \text { (see note) } \\ \text { Molybdenum } & 0.22 \% \text { (see note) }\end{array}$

Note: Actual \% of first and second batch. 
June 28, 1962

Amended Oct. 17, 1963

3. COMPONENT DIMENSIONS AND/OR TOLERANCES

3.1 Aluminum Can

$\begin{array}{ll}\text { O.D. (before die-sizing) } & 0.962 " \pm .002 \\ \text { I.D. } & 0.834 " \pm .002 \\ \text { Length } & 13 \text { inches } \pm 1 / 32 \\ \text { Can Wall (after die- } & 0.050 " \pm .005\end{array}$

3.2 Aluminum End Cap

O.D.

Thickness

$3.3 \underline{\text { D-Bar }}$

3.3 D-Bar $.834^{\prime \prime} \pm 0.001$

$.203 \pm 0.003$
Length
$12.656^{\prime \prime} \pm .005$
width
$0.625^{\prime \prime} \pm .005$
Thickness
$0.220^{\prime \prime} \pm .005$
Surface
approximately 60 RMS

3.4 Stainless Steel sheath

Thickness

0.015 minimum

\subsection{Cobalt strip}

$\begin{array}{ll}\text { Thickness } & 0.060 " \pm .001 \\ \text { Width } & 0.640^{\prime \prime} \pm .002 \\ \text { Length } & 12 . \text { inches } \pm .010 \\ \text { Straightness } & \\ \quad-\text { on flat } & \\ \quad-\text { on edge } & 0.005 \text { maximum }\end{array}$

\subsection{Sheathed Cobalt Strips}
Length
$129 / 16^{\prime \prime} \pm 1 / 32$
width
$0.760^{\prime \prime} \pm .005$
Thickness
$0.092 " \pm .002$
(Thickness not to vary more than .0005 from one end to the other.)
straightness
- on flat 0.005 maximum
- on edge.' 0.005 maximum end to end
Weld
a) No pin holes or porosity.
b) No weld overhang. 
Surface

Ends

\subsection{Finished slug Dimensions}

Length

O.D.

Weld Overhang

weld Height

straightness

Surface a) Approximately 20 RMS.

b) No burrs. Dents and gouges not to exceed 0.005 .

All end corners to be rounded, $1 / 32$ radius minimum.
Up to $131 / 16^{\prime \prime} \pm 1 / 32$

tolerance.

$0.940 \pm .002$ and as noted below.

$0.002 "$ Maximum on radius

Not to exceid boss on cap.

Must pass through a full

length 0.9493 point contact gauye. No dents, gouges or scratches exceeding 1) .010" on cylindrical surfaces or .005" on weld bead, 2) .020" on caps.

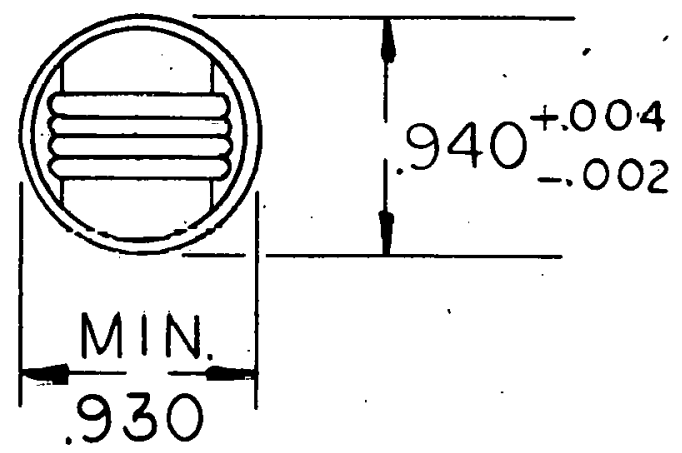




\section{CLEANING PROCEDURES}

\subsection{Cobalt}
a. Vythene vapor degrease.
b. Hot water rinse $\left(170-195^{\circ}\right.$ F.).
c. Methanol dehydration.
d. Hot air drying (approximately $250^{\circ}$ F.).

\subsection{Aluminum}

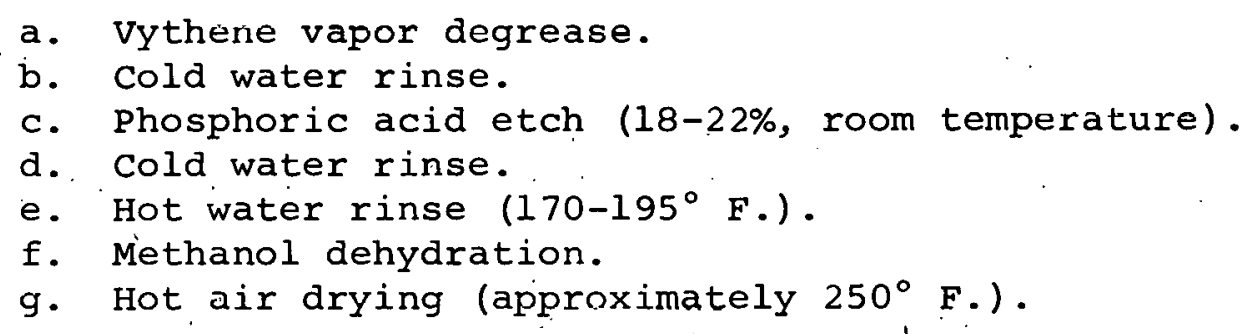

\subsection{Stainless steel}
a. Vythene vapor degrease.
b. Cold water rinse.
c. Methanol dehydration.
d. Hot, air drying (approximately $250^{\circ}$ F.).

Note: All parts to be handled with clean, white gloves after cleaning. Store in closed containers if not used immediately. 
Spec R155-Wl

June 28, 1962

Amended Oct. 17, 1963

\section{DESCRIPTION OF COBALT ENCAPSULATION}

\section{FIRST STAGE ENCAPSULATION - STAINLESS STEEL}

5.1 All parts to be inspected for dimensions and quality before cleaning.

5.2 Clean as described previously.

5.3 Inspect for cleanliness using white gloves.

\subsection{Fabrication of Spurre}

This operation must be performed with gloves and/or tongs as noter helow, all cquipmenl dill illas to ho troc of oil.

a. Wearing gloves, put clean tube into flat portion of pressing die and flatten to a predetermined height (approximately 1/8"). Then move flattened tube over to portion of die containing the final forming slot, insert clean stainless steel internal sizing strip and press, using approximately 20 tons of pressure.

b. Return flattened ohcath to melharol bath and air drier.

c. Wearing gloves, inspect. fnr scratches, imperfeclious and cleanliness.

d. Wearing gloves, insert clean cobalt strip and the two stainless steel end pieces. Keep end pieces flush with ends of tube. Put into clean copper welding $j$ ig and weld without using filler rod.

e. Inspect for weld overhang and sound welds.

f. Leak test, using kerosene bubble test at 28 " $\mathrm{Hg}$ vacuum.

g. Repeat cleaning cycle and store in plastic bag, laying flat in suitable container.

h. Just before final assembly into outer can, flatten again in hydraulic press to remove all springback. 
June 28, 1962

Amended Oct. 17, 1963

5.5 Welding Data (Stainless)

$\begin{array}{ll}\text { Welding Polarity } & \text { DC SP } \\ \text { Welding Current } & 50-70 \mathrm{Amp} \\ \text { Position } & \text { Horizontal } \\ \text { Electrode } & 1 / 16 \text { diameter } \\ & \text { thoriated tungsten } \\ & \text { (pointed) } \\ \text { Torch } & \text { HW20 } \\ \text { Cup Size } & \# 5 \\ \text { Argon Flow } & 10 \mathrm{CFH} \\ \text { Number of Passes } & 1\end{array}$




\section{SECOND STAGE ENCAPSULATION - ALUMINUM}

6.1 All parts to be inspected for dimensions and quality before cleaning.

6. 2 Clean as described previously.

6.3 Inspect for cleanliness using white gloves.

6.4 Insertion of first stage into aluminum using gloves and clean parts only assemble the slug as follows:

a. Weld numbered end cap on tapered end of aluminum tube.

b. Bell-mouth other end on inside to a maximum inside diameter of .810 tapering dowil lu .834 within $b / y "$. Remove burrs from edge of tube.

c. Repeat methanol and air drying cycle.

.d. Insert 4 cobalt sources and 2 aluminum "D" bars into aluminum tube. Locate " $D$ " bars in same plane as numbers on end cap. (See paragraph 7.10 for illustration.) Total thickness of sandwich to be .835-.838.

e. Insert internal sizing rod into open end. Coat slug with Door-Ease stick and push assembly through external sizing die.

f. Remove excess lubricant before pulling out sizing rod.

g. Dip open end into methanol with closed end up and air dry.

h. Insert clean end cap with mating number and same orientation.

i. Cut off flash of sizing operation level with cap without using lubricant (approximately $5 / 8^{\prime \prime}$ ).

j. Wipe this end clean with methanol and make final weld.

k. Leak test using kerosene bubble test at. 28" Hg vacuum. Inspect for final dimensions and quality using paragraph 7.0 . 
Spec R155-W1

June $28,1.962$

Amended Oct. 17, 1963

1. Repeat vapor degrease and cold water rinse.

m. Wrap in paper towel and insert into: cardboard tube.

6.5 Welding Data (Aluminum)

Welding Polarity
Welding Current
Position
Electrode
Cup size
Torch
Argon Flow
Helium Flow
Arc Length
Number of Passes
A.C. High Frequency 55-65 Amps

Horizontal, Semiautomatic .040" diameter zirtung (ball pointed)

\#6

HW 20

$14 \mathrm{CFH}$

$25 \mathrm{CFH}$

$1 / 16^{\prime \prime}$

$1 \frac{1}{4}$ 
Spec R155-W1

June 28, 1962

Amended Oct. 17, 1963

\section{INSPECTION CRITERIA FOR COBALT SLUGS}

7.1 Each slug must have an O.D. of $0.940^{\prime \prime} \pm: 884$ across the solid portion.

7.2 Each slug must pass through a full length 0.949" I.D., 3 points of contact, tube gauge or it will be rejected.

7.3 Each slug must be leak tight as determined by a kerosene bubble test operated at $28 " \mathrm{Hg}$ vacuum or it will be rejected.

7.4 Ten per cent of the slugs received at SRP will be destructively examined by sectioning the slug at approximately $2.5,6.5$ and 10.5 inches from one end. A surface will be polished and the diametrical gap, perpendicular to the flat face of the cobalt strip, will be measured with a standard Tukon hardness tester microscopo. If the lotal radial gap across a section exceeds .003", then the entire batch will be rejected. In determining the total diametrical gap, the three center gaps are to be excluded from consideration since these do not affect heat transfer. If any one gap measurement exceeds 0.002", the entire batch will be rejected. Measurements to be averaged from edge to center.

7.5 The outside of the aluminum can on each slug must be free of dents, scratches or gouges greater than 0.010" on lateral surfaces, greater than 0.020" on the end caps, and greater than $0.005 "$ on the weld bead or the slug will be rejected.

7.6 Throat thickness of the stainless stecl and aluminum welds must be greater than 0.010", as determined by destructive examination of sample slug, or the entire lot will be rejected.

7.7 The height of the aluminum weld must not exceed the height of the boss or the slug will be rejected.

7:8 Each sectioned part of each slug destructively tested will be examined for foreign material and if detected will be sufficient cause for the rejection of the entire lot.

7.9 Each slug must be identified on both ends by source and serial number. For example, BNL slugs should be identified by a "B". Production lot numbers to be located alongside of "B". Serial numbers should be placed immediately below the "B". Letters and numerals to be $1 / 8$ " high and approximately $1 / 32$ " deep.

Serial numbers of slugs submitted to SRP prior to process approval should be numbered beginning with the numeral 1 
and numbered consecutively. After process approval is granted, slugs should be numbered beginning with 100. Each separate production lot should be numbered beginning with the next higher one-hundred series. For example, the number 1-10 would indicate the tenth slug of the first lot, and 2-10 would designate the tenth slug of the second lot.
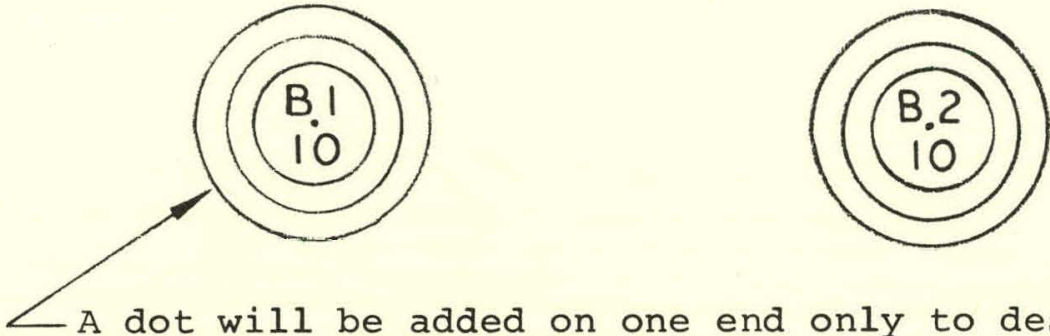

"A" end (see BNL inspection sheet).

7.10 The location of the numbers also indicates the location of the "D" bars within the outer tube. This information will be required when sources are to be decanned.

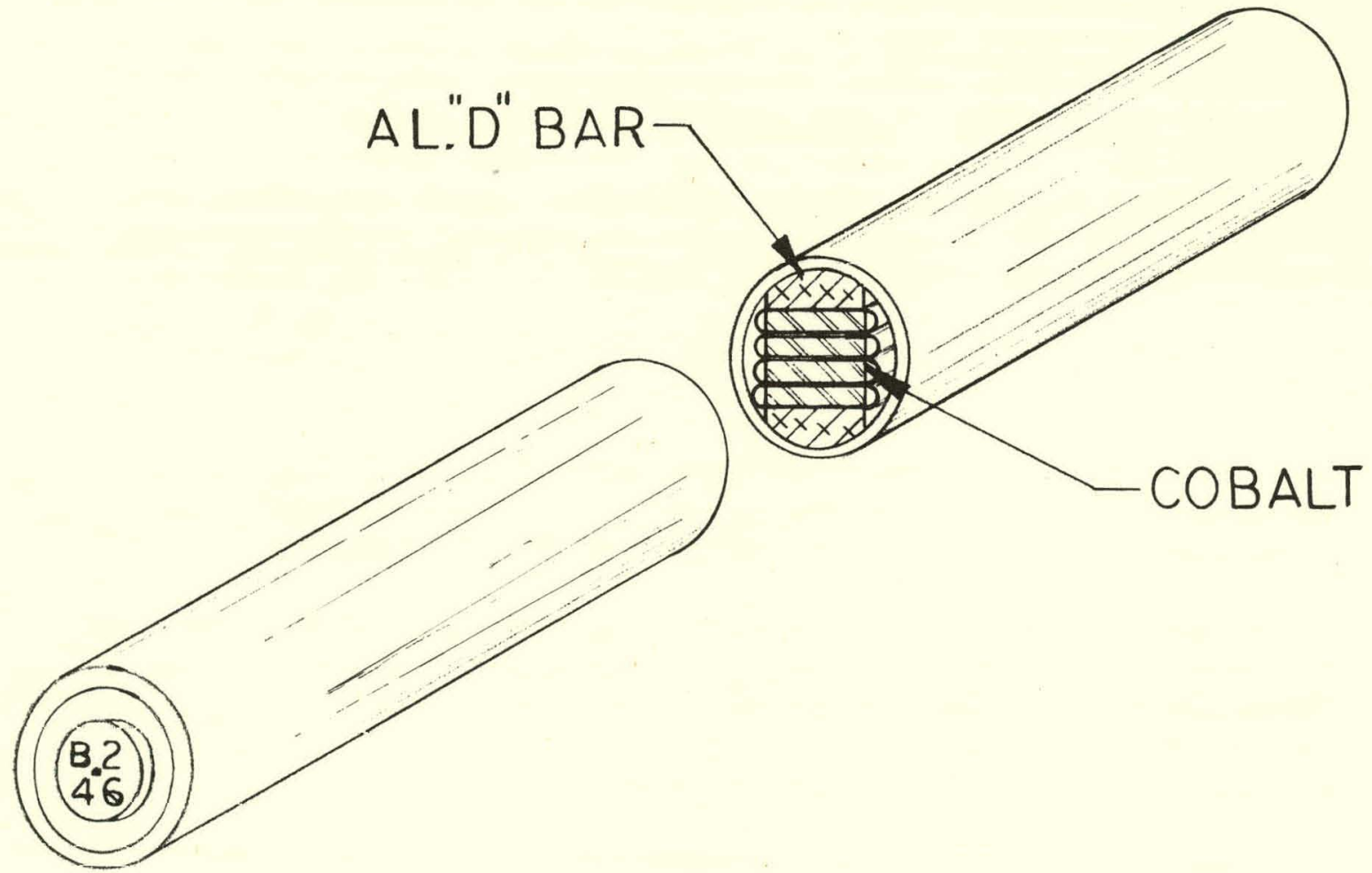

